\title{
Research on Spatial Distribution Characteristics and Influencing Factors of Sports Fields in China
}

\section{- Spatial Econometric Test Based on the Data of the 6th National Field Census}

\author{
Lei Lei \\ Sports department, Northwest A\&F University dept of Physical Education, \\ Xianyang,Shaanxi 712100,China
}

\begin{abstract}
Based on the data of the 6th national field census, taking the number of sports fields in 31 provinces, cities and autonomous regions of our country as the object, this paper analyzes and discusses the spatial characteristics of the distribution of sports fields in our country by using the spatial measurement method. The OLS estimation, SLM estimation and SEM estimation of the number of sports fields and related influencing factors are established. After the spatial dependence test, the research shows that the spatial econometric regression model is better than the ordinary least squares regression model, which shows that the estimation method considering spatial dependence can better represent the spatial distribution characteristics of sports fields in China. SEM was confirmed to be the best model by correlation discrimination test, and corrected the OLS model's general underestimation of the government's influence on the distribution of sports fields.
\end{abstract}

KEYWORDS: sports field; spatial dependence; spatial econometric model

\section{Introduction}

The arrival of the 2014 document "Opinions of the State Council on Accelerating the Development of Sports Industry and Promoting Sports Consumption" (State issue [2014] No. 46) has brought great opportunities to the development of China's sports industry, national fitness has become a national strategy. At this time, it is of great practical significance to deeply discuss the current situation of the allocation level of sports resources in China in order to promote the rapid development of China's sports cause. With the rapid development of our national economy, the 
promotion of residents' health awareness and the expansion of fitness demand, the requirements for sports space and stadium setting are also getting higher and higher. With the rapid development of sports in China, a series of problems such as the rationalization of the distribution of sports field setting and the equalization of urban and rural distribution have become important decisions that the government must face. At present, from the perspective of research breadth, domestic scholars mainly focus on the research on the current situation, principles, objectives and related theories of the layout of sports field, while the research on the evolution process, development trend, influencing factors and driving mechanism of the spatial layout of sports field has only just begun. Through the research on the distribution of sports fields' facilities in 31 provinces, cities and autonomous regions in our country, this study attempts to explore the influential factors and spatial dynamics in the construction and development of sports fields in various provinces and regions, and then provide policy suggestions for reasonable development and utilization of sports fields facilities.

\section{Review of Theory and Research}

The distribution of sports field has always been one of the focuses of research on sports resources at home and abroad. Foreign scholars tend to predict the future development trend of sports field layout. Tracy ${ }^{[16]}$ and others put forward the main reasons that affect the changes in the layout of sports field through analyzing the characteristics of the sports field layout of the current American cities and major leagues period. $\mathrm{DAADE}^{[17]}$ and others believe that the field location needs to be studied from a geographical point of view so as to improve the accuracy of the location of field construction. Regarding the research on the current situation of sports field layout by domestic scholars, Yin Ling ${ }^{[18]}$ (2008) pointed out that the shortage of sports fields facilities is the bottleneck restricting the sustainable development of the city's national fitness. The allocation of resources is not balanced, the design is not well targeted, and the function is relatively single. Gao Yali and others ${ }^{[19]}$ think that there are some problems in the development and utilization of sports field in China, such as total cardinal vague, unreasonable regional distribution and structure, etc.

In terms of the influencing factors of the distribution of sports field, foreign studies on the influencing factors of the distribution of sports field are very extensive and subtle. FEYZANT ${ }^{[20]}$ proposes that the regional characteristics of sports facilities are the main factors affecting park facilities and sports and entertainment facilities, specifically including population density, age, gender, family structure and size, income level, educational background, means of transportation and personal interest, etc. These factors will affect the quality of public sports settings. However, the evaluation system of domestic scholars on the influencing factors of the distribution of sports field is very complicated. Many scholars study single dominant factors as evaluation. Zeng Jianming and others (2014) conducted a study on the spatial layout of China's large stadiums (gymnasiums), pointing out that the layout of stadiums (gymnasiums) lacks 
rationality and is too centralized. It does not fit well with the urban public space. Xu Yueyun and others (2016) pointed out that the spatial distribution of sports field in Quanzhou city is uneven, mainly between urban and rural areas and between the old town and the new town.

China launched the sixth national sports fields' census in 2014. Through the analysis of the census, the distribution of sports field in China is uneven, with the largest number of sports fields in the eastern region accounting for $43.29 \%$, per capita 1.81 square meters, far higher than the central and western regions ${ }^{[3]}$. The sixth national sports fields census shows that there are obvious differences in the distribution of sports fields in China. Therefore, this paper selects the number of sports fields in 31 provinces, cities and autonomous regions in China as the research object. Taking full account of geographical dependence, i.e. spatial autocorrelation and spatial weight, a spatial econometric model is constructed to study the distribution characteristics of sports field in China, providing a perspective of spatial econometric research for the study of sports field distribution.

\section{Data, Samples and Methods}

\subsection{Data and Samples}

This paper uses the annual data of provinces and regions (provinces, autonomous regions, and municipalities directly under the central government), and the samples are taken from the 2013 census data. Main sources of data: (1) 6th national sports fields census (2014); (2) China statistical yearbook (2014); (3) China sports statistics yearbook (2013 - 2014); (4) provinces (autonomous regions and municipalities) statistical yearbook (2013 - 2014).In addition, due to the availability of data and the relevance of sports field, Hong Kong, Macao and Taiwan regions have been excluded, resulting in the formation of layout data on the distribution of sports field in China. Moreover, there are many factors affecting the number (distribution) of fields. In view of the availability of data, the following variables are selected:

(1) The level of sports field. This study chose the number of sports fields to represent the level of sports field. The data came from the 6th national sports field census, which was conducted in individual units.

(2) Resident population. The resident population selected in this article is taken from the resident population of all provinces and regions in China statistical yearbook in 2013. The unit is $10^{4}$ people.

(3) Economic level. This study chose gross domestic product (GDP) to measure the level of economic development. In order to eliminate the influencing factors of prices, the GDP of that year was adjusted to the actual GDP based on 2013 according to the GDP index. The data came from the 2014 China statistical yearbook. The unit is $10^{, 4}$ yuan. 
(4) Area of sports field. The selection of the area of the sports field studied by this paper is the actual area of the construction of the sports field. The data came from the 6th national sports field census, the unit is $\mathrm{km}^{2}$.

(5) Field type. Sports fields are mainly divided into indoor field and outdoor field. This study chose the number of outdoor field and indoor sports field to represent the types of field. The data came from the 6th national sports census, which was conducted in individual units.

(6) Number of urban and rural fields. The number of urban and rural fields reflects the equalization of sports fields in urban and rural areas. Based on the feasibility of the available data, this paper chose the cumulative number of urban field and the cumulative number of township cities to represent the value of the number of urban and rural fields. The data came from the 6th national sports census, which was conducted in individual units.

(7) Investment amount. The amount of investment in sports field in this study includes financial allocation, subject matter public welfare funds, self-financing by the unit and other income. The data came from the 6th national sports field census. The unit is $10^{4}$ yuan.

(8) Other factors. Based on the results of the 6th national sports field census, this study included the number of field practitioners and the number of audience seats as other factors affecting the distribution of fields. The units are person and individual respectively.

Because the above index variables have different units and different degrees of variation, it is difficult to explain them in practice with regression model. Therefore, in SPSS23.0 software, all data of dependent variables and independent variables are standardized. The data standardization method used in this study is Z - score standardization method, which standardizes the data based on the mean and standard deviation of the original data. Its formula is equal to:

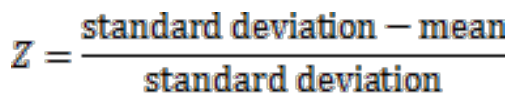

The standardized data results are shown in table 1: 
Academic Journal of Humanities \& Social Sciences

ISSN 2616-5783 Vol. 1, Issue 1: 47-58, DOI: 10.25236/AJHSS.040007

Table 1 Results of standardized data on field distribution indicators of 31 provinces in China

\begin{tabular}{|c|c|c|c|c|c|c|c|c|c|c|c|}
\hline Provinces & $\begin{array}{c}\text { Number of } \\
\text { fields }\end{array}$ & $\begin{array}{c}\text { Resident } \\
\text { population. }\end{array}$ & $\begin{array}{l}\text { Per capita } \\
\text { GDP }\end{array}$ & $\begin{array}{c}\text { Number of } \\
\text { outdoor fields }\end{array}$ & $\begin{array}{l}\text { Number of } \\
\text { indoor fields }\end{array}$ & $\begin{array}{l}\text { Number of } \\
\text { urban fields }\end{array}$ & $\begin{array}{l}\text { Number of } \\
\text { rural fields }\end{array}$ & Covered area & $\begin{array}{c}\text { Investment } \\
\text { amount }\end{array}$ & \begin{tabular}{|c|}
$\begin{array}{c}\text { Number of } \\
\text { field } \\
\text { practitioners }\end{array}$ \\
\end{tabular} & Audience seat \\
\hline \begin{tabular}{|c|}
$\begin{array}{c}\text { HeiLongijang } \\
\text { province }\end{array}$ \\
\end{tabular} & -0.697 & -0.184 & -0.166 & -0.318 & -0.724 & -0.492 & -0.874 & -0.379 & 0.269 & -0.222 & -0.174 \\
\hline \begin{tabular}{|c|} 
Xinjiang \\
autonomous \\
region
\end{tabular} & -0.74 & -0.752 & -0.335 & -0.487 & -0.74 & -0.798 & -0.472 & -0.554 & -0.66 & -0.726 & -0.682 \\
\hline $\begin{array}{c}\text { Shanxi } \\
\text { province }\end{array}$ & 0.306 & -0.258 & -0.336 & -0.4 & 0.427 & -0.396 & 1.401 & -0.339 & -0.335 & 0.283 & -0.106 \\
\hline \begin{tabular}{|c|} 
Ningxia \\
autonomous \\
region
\end{tabular} & -1.149 & -1.334 & -0.589 & -0.643 & -1.171 & -0.977 & -1.168 & -1.062 & -0.827 & -1.109 & -1.217 \\
\hline \begin{tabular}{|c|} 
Tibet \\
autonomous \\
region
\end{tabular} & -1.302 & -1.458 & -0.672 & -0.741 & -1.324 & -1.185 & -1.193 & -1.261 & -0.919 & -1.29 & -1.36 \\
\hline $\begin{array}{l}\text { Shandong } \\
\text { province }\end{array}$ & 1.35 & 1.949 & 0.471 & -0.065 & 1.542 & 0.912 & 1.763 & 2.381 & 1.995 & 1.133 & 1.729 \\
\hline $\begin{array}{c}\text { Henan } \\
\text { province }\end{array}$ & 0.834 & 1.833 & -0.416 & -0.446 & 1.035 & 0.409 & 1.347 & 0.57 & -0.471 & 1.29 & 0.129 \\
\hline $\begin{array}{c}\text { Jiangsu } \\
\text { province }\end{array}$ & 1.938 & 1.3 & 0.899 & 3.56 & 1.473 & 2.625 & 0.342 & 2.036 & 1.914 & 1.109 & 1.125 \\
\hline $\begin{array}{c}\text { Anhui } \\
\text { province }\end{array}$ & 0.012 & 0.61 & -0.7 & -0.121 & 0.038 & 0.063 & -0.076 & 0.143 & -0.428 & -0.292 & -0.204 \\
\hline $\begin{array}{c}\text { Hubei } \\
\text { province }\end{array}$ & 0.742 & 0.527 & -0.439 & 0.332 & 0.773 & 0.797 & 0.475 & 0.261 & -0.444 & 0.205 & 0.275 \\
\hline $\begin{array}{l}\text { Zhejiang } \\
\text { province }\end{array}$ & 2.013 & 0.418 & 1.1 & 2.937 & 1.685 & 1.601 & 2.229 & 0.401 & 0.364 & 1.227 & 0.775 \\
\hline $\begin{array}{c}\text { Jiangxi } \\
\text { province }\end{array}$ & 0.384 & 0.065 & -0.625 & -0.059 & 0.447 & 0.208 & 0.586 & 0.032 & -0.593 & 0.082 & -0.061 \\
\hline $\begin{array}{c}\text { Hunan } \\
\text { province }\end{array}$ & 0.134 & 0.527 & -0.558 & -0.087 & 0.17 & 0.167 & 0.048 & 0.221 & -0.292 & -0.018 & 0.323 \\
\hline $\begin{array}{c}\text { Yunnan } \\
\text { province }\end{array}$ & 0.192 & 0.125 & -0.826 & -0.391 & 0.297 & -0.304 & 0.972 & -0.107 & -0.564 & -0.327 & 0.181 \\
\hline $\begin{array}{l}\text { Guizhou } \\
\text { province }\end{array}$ & -0.574 & -0.304 & -1.025 & -0.661 & -0.516 & -0.685 & -0.256 & -0.769 & 0.819 & -0.368 & -0.69 \\
\hline $\begin{array}{c}\text { Fujian } \\
\text { province }\end{array}$ & 0.278 & -0.206 & 0.215 & 0.532 & 0.208 & 0.079 & 0.544 & -0.061 & -0.345 & -0.524 & 0.138 \\
\hline \begin{tabular}{|c|}
$\begin{array}{c}\text { Guangxi } \\
\text { autonomous } \\
\text { region }\end{array}$ \\
\end{tabular} & 0.598 & 0.136 & -0.683 & -0.466 & 0.771 & 0.227 & 1.075 & -0.15 & -0.071 & 0.483 & 1.691 \\
\hline $\begin{array}{c}\text { Guangdong } \\
\text { province }\end{array}$ & 2.621 & 2.279 & 0.837 & 1.303 & 2.703 & 3.135 & 1.152 & 3.279 & 3.603 & 3.802 & 3.242 \\
\hline $\begin{array}{l}\text { Hainan } \\
\text { province }\end{array}$ & -1.131 & -1.247 & -0.54 & -0.72 & -1.135 & -0.968 & -1.137 & -0.707 & -0.895 & -0.917 & -1.2 \\
\hline \begin{tabular}{|l|} 
Jilin province \\
\end{tabular} & -0.881 & -0.576 & -0.258 & $\begin{array}{ll}-0.393 \\
\end{array}$ & -0.917 & -0.745 & $\begin{array}{ll}-0.9 \\
\end{array}$ & -0.472 & -0.656 & $\begin{array}{ll}-0.528 \\
\end{array}$ & $\begin{array}{ll}-0.594 \\
\end{array}$ \\
\hline \begin{tabular}{|c|}
$\begin{array}{l}\text { Liaoning } \\
\text { province }\end{array}$ \\
\end{tabular} & -0.024 & 0.017 & 0.287 & 0.013 & -0.03 & 0.21 & -0.407 & 0.352 & 0.622 & -0.077 & 0.746 \\
\hline $\begin{array}{l}\text { Tianjin city } \\
\end{array}$ & -1.019 & -1.038 & 1.264 & $\begin{array}{ll}-0.507 \\
\end{array}$ & \begin{tabular}{|l|}
-1.051 \\
\end{tabular} & $\begin{array}{l}-0.833 \\
\end{array}$ & $\begin{array}{ll}-1.088 \\
-1.0\end{array}$ & \begin{tabular}{|l|l|}
-0.681 \\
\end{tabular} & -0.6 & $\begin{array}{l}-1.015 \\
-1.0\end{array}$ & -1.053 \\
\hline $\begin{array}{c}\text { Qinghai } \\
\text { province }\end{array}$ & -1.249 & -1.361 & -0.581 & -0.733 & -1.265 & -1.096 & -1.21 & -1.154 & -0.817 & -1.215 & -1.288 \\
\hline $\begin{array}{c}\text { Gansu } \\
\text { province }\end{array}$ & -0.627 & -0.637 & -0.821 & -0.643 & -0.579 & -0.767 & -0.246 & -0.73 & -0.821 & -0.674 & -0.816 \\
\hline $\begin{array}{c}\text { Shaanxi } \\
\text { province }\end{array}$ & -0.353 & -0.209 & -0.578 & -0.532 & -0.292 & -0.376 & -0.231 & -0.482 & 0.072 & -0.104 & -0.207 \\
\hline $\begin{array}{c}\text { Inner } \\
\text { Mongolia } \\
\text { autonomous } \\
\text { region } \\
\end{array}$ & -0.764 & -0.667 & 0.354 & 0.005 & -0.866 & -0.464 & -1.084 & -0.455 & -0.267 & -0.799 & 0.006 \\
\hline Chongqing & \begin{tabular}{|l|l|}
-0.338 \\
\end{tabular} & $\begin{array}{l}-0.496 \\
\end{array}$ & $\begin{array}{l}-0.492 \\
\end{array}$ & $\begin{array}{ll}-0.501 \\
\end{array}$ & \begin{tabular}{|c|}
-0.281 \\
\end{tabular} & \begin{tabular}{|c|}
-0.151 \\
\end{tabular} & $\begin{array}{l}-0.569 \\
\end{array}$ & \begin{tabular}{|c|c|}
-0.477 \\
\end{tabular} & 1.091 & $\begin{array}{l}-0.372 \\
\end{array}$ & 0.317 \\
\hline $\begin{array}{c}\text { Hebei } \\
\text { province }\end{array}$ & 0.335 & 1.081 & \begin{tabular}{l|}
-0.1 \\
\end{tabular} & \begin{tabular}{l|l|}
-0.302 \\
\end{tabular} & 0.441 & 0.013 & 0.793 & 0.856 & -0.479 & 0.47 & -0.265 \\
\hline Shanghai & \begin{tabular}{|l|l|}
-0.397 \\
\end{tabular} & $\begin{array}{l}-0.697 \\
\end{array}$ & 3.281 & $\begin{array}{l}1.174 \\
\end{array}$ & \begin{tabular}{|c|}
-0.688 \\
\end{tabular} & $\begin{array}{l}0.118 \\
\end{array}$ & -1.162 & \begin{tabular}{|l|l|l|}
-0.47 \\
\end{tabular} & 0.172 & $\begin{array}{l}-0.082 \\
\end{array}$ & $\begin{array}{l}-0.833 \\
\end{array}$ \\
\hline Beijing & \begin{tabular}{|c|c|}
-0.911 \\
\end{tabular} & $\begin{array}{c}-0.806 \\
-\end{array}$ & 2.691 & \begin{tabular}{|c|c|c|}
-0.218 \\
\end{tabular} & \begin{tabular}{|c|}
-0.987 \\
\end{tabular} & -0.676 & $\begin{array}{l}-1.089 \\
\end{array}$ & $\begin{array}{l}-0.324 \\
\end{array}$ & -0.252 & 0.001 & -0.45 \\
\hline $\begin{array}{l}\text { Sichuan } \\
\text { province }\end{array}$ & 1.361 & -0.661 & \begin{tabular}{|l|}
-0.422 \\
\end{tabular} & 0.559 & 0.348 & 0.436 & 0.088 & $\begin{array}{ll}-0.185 \\
\end{array}$ & 0.574 & 0.524 & 0.524 \\
\hline
\end{tabular}

3.2 Method for establishing spatial constant coefficient regression model

The spatial constant coefficient regression model is an important method of spatial measurement model. It mainly introduces spatial effects (spatial correlation and spatial heterogeneity), i.e. considering spatial dependence. It also refers to spatial weight index. ${ }^{[2]}$ According to different ways of spatial dependence, the spatial constant coefficient regression model can be divided into Spatial Lag Model, SLM and Spatial Error Model, SEM. 
(1) Spatial lag model (SLM)

It is to explore whether variables have spillover effects in a region. The model is as follows:

$$
\mathrm{y}=\rho \mathrm{Wy}+\beta \mathrm{X}+\varepsilon
$$

Wherein $\mathrm{y}$ is a dependent variable, $\mathrm{X}$ is an independent variable matrix of $\mathrm{n} * \mathrm{k}$ ( $\mathrm{n}$ is the number of regions, $\mathrm{k}$ is the number of independent variables), $\mathrm{W}$ is the proof of $n * n$ spatial weight, and $\rho$ is the spatial lag coefficient. $\beta$ is the regression coefficient of spatial independent variables, $\varepsilon$ is the random error term.

(2) Spatial error model (SEM)

It is to discuss whether there is sequence relation between error terms. The model is as follows:

$$
\begin{aligned}
& y=\beta X+\varepsilon \\
& \varepsilon=\gamma W \varepsilon+\mu
\end{aligned}
$$

Where $\gamma$ is the spatial error coefficient, $\mu$ is the random error term obeying the positive distribution, and other parameters have the same meaning as SLM.

(3) SLM and SEM model selection.

Because both SLM and SEM consider spatial dependence, which model is better still needs to be identified. This paper refers to the discrimination method proposed by Jiang Lei in 2011.There are mainly natural Log likelihood (LogL), Akaike information criterion, AIC, Schwartz criteria, SC, the larger LogL, the smaller AIC and SC, the better the effect of the model. ${ }^{[2]}$

\section{Construction of spatial measurement model for distribution of sports field in China}

The construction of a spatial measurement model for the distribution of sports field models is to overcome the Ordinary Least Square regression model, ignoring the defects of spatial dependence, improving the estimation goodness, and giving a reasonable explanation for the imbalance and heterogeneity of geographic space.

\subsection{General least squares estimation modeling}

In order to overcome the problem of heteroscedasticity that often exists in crosssectional data, the standardized data is modeled (the same is true for SLM and SEM modeling).In order to facilitate comparison, the OLS is used directly to build the model without considering the spatial dependence (table 3).Since there are 1 independent variable and 10 dependent variables and, 11 variables in total, the multicollinearity problem may arise, which needs to be examined. Through the variance inflation factor (VIF) test, when VIP $>10$, it indicates that there exists multicollinearity. This variable should be removed, otherwise it will affect the estimation result. there is no multicollinearity when VIF $<10$.Through examination, 
8 of the 10 independent variables in this study are less than 10, and the VIF values of the number of indoor field and the number of urban field are greater than 10 , so these two variables are excluded.

Table 2 analysis results of variance inflation factor for field distribution level

\begin{tabular}{|c|c|c|c|c|c|c|c|c|c|c|}
\hline Indicators & $\begin{array}{c}\text { Resident } \\
\text { population }\end{array}$ & $\begin{array}{c}\text { Per capita } \\
\text { GDP }\end{array}$ & $\begin{array}{c}\text { Number of } \\
\text { outdoor } \\
\text { fields }\end{array}$ & $\begin{array}{c}\text { Number of } \\
\text { indoor } \\
\text { fields }\end{array}$ & $\begin{array}{c}\text { Number of } \\
\text { urban } \\
\text { fields }\end{array}$ & $\begin{array}{c}\text { Number of } \\
\text { rural } \\
\text { fields }\end{array}$ & $\begin{array}{c}\text { Covered } \\
\text { area }\end{array}$ & $\begin{array}{c}\text { Investment } \\
\text { amount }\end{array}$ & $\begin{array}{c}\text { Number of } \\
\text { field } \\
\text { practitione } \\
\text { rs }\end{array}$ & $\begin{array}{c}\text { Audience } \\
\text { seat }\end{array}$ \\
\hline VIF & 9.047 & 2.722 & 5.73 & 12.685 & 53.234 & 4.77 & 8.522 & 5.201 & 9.163 & 9.402 \\
\hline
\end{tabular}

Judging from OLS model, the adjusted goodness of fit reached 0.945, which was good. Moreover, the number of outdoor field, the number of rural field and the number of audience seats passed the $5 \%$ coefficient significance test. Among them, the number of outdoor field, the number of rural field, the number of audience seats and the number of field practitioners are the decisive factors for the number of fields. However, from the coefficient point of view, the symbol of GOP and construction area per capita is contrary to expectation. The result shows that the higher the GDP per capita, the fewer the distribution of sports fields in the region. The larger the covered area, the fewer fields are distributed. Since OLS analysis does not consider spatial dependence, it needs to be discussed after SLM and SEM analysis.

\subsection{Spatial econometric modeling and analysis}

Since it is impossible to determine empirically whether a spatial lag model or a spatial error model should be established, it is necessary to establish it at the same time before checking which model is more suitable. The estimated results of the model are shown in table 4. 
Academic Journal of Humanities \& Social Sciences

ISSN 2616-5783 Vol. 1, Issue 1: 47-58, DOI: 10.25236/AJHSS.040007

Table 3 OLS estimation results

\begin{tabular}{|c|c|c|c|c|}
\hline variable & coefficient & $\begin{array}{l}\text { standard } \\
\text { error }\end{array}$ & t statistic & $\begin{array}{l}\text { probability } \\
\text { value }\end{array}$ \\
\hline $\begin{array}{l}\text { Number of } \\
\text { fields(c) }\end{array}$ & 0.0135 & 0.0448 & 0.3018 & 0.7655 \\
\hline $\begin{array}{c}\text { Resident } \\
\text { population } \\
\end{array}$ & 0.0749 & 0.1043 & 0.7182 & 0.4801 \\
\hline Per capita GDP & -0.0992 & 0.056 & -1.7707 & 0.0904 \\
\hline $\begin{array}{c}\text { Number of } \\
\text { outdoor fields }\end{array}$ & 0.3868 & 0.0631 & 6.127 & 0 \\
\hline $\begin{array}{l}\text { Number of rural } \\
\text { fields }\end{array}$ & 0.3399 & 0.0882 & 3.8536 & 0 \\
\hline Covered area & -0.0233 & 0.0945 & -0.2469 & 0.8072 \\
\hline $\begin{array}{c}\text { Investment } \\
\text { amount }\end{array}$ & 0.0402 & 0.0936 & 0.4295 & 0.6716 \\
\hline $\begin{array}{l}\text { Number of field } \\
\text { practitioners }\end{array}$ & 0.1944 & 0.1006 & 1.9323 & 0.066 \\
\hline Audience seat & 0.2461 & 0.1073 & 2.294 & 0.031 \\
\hline $\mathrm{R} 2$ & 0.9596 & & & \\
\hline R2adj & 0.945 & & & \\
\hline $\log L$ & 5.473 & & & \\
\hline AIC & 7.053 & & & \\
\hline $\mathrm{SC}$ & 19.9598 & & & \\
\hline
\end{tabular}

Published by Francis Academic Press, UK

$-54-$ 
Table 4 SLM and SEM estimation results

\begin{tabular}{|c|c|c|c|c|c|c|c|c|}
\hline & \multicolumn{4}{|c|}{ SLM } & \multicolumn{4}{|c|}{ SEM } \\
\hline variable & coefficient & $\begin{array}{l}\text { standard } \\
\text { error }\end{array}$ & $t$ statistic & \begin{tabular}{|c}
$\mathrm{p}$ \\
probability \\
value
\end{tabular} & coefficient & $\begin{array}{l}\text { standard } \\
\text { error }\end{array}$ & t statistic & $\begin{array}{c}\mathrm{p} \\
\text { probability } \\
\text { value }\end{array}$ \\
\hline $\begin{array}{l}\text { Number of } \\
\text { fields (c) }\end{array}$ & 0.007 & 0.0396 & 0.4838 & 0.8573 & 0.0138 & 0.3607 & 0.3847 & 0.7009 \\
\hline $\begin{array}{l}\text { Resident } \\
\text { population }\end{array}$ & 0.0363 & 0.0911 & 0.1797 & 0.4849 & 0.0736 & 0.0873 & 0.8427 & 0.3993 \\
\hline $\begin{array}{c}\text { Per capita } \\
\text { GDP }\end{array}$ & -0.1064 & 0.0493 & 0.6983 & 0.031 & -0.0992 & 0.0466 & -0.2127 & 0.033 \\
\hline $\begin{array}{c}\text { Number of } \\
\text { outdoor } \\
\text { fields }\end{array}$ & 0.3829 & 0.0539 & -2.1559 & 0 & 0.3843 & 0.0527 & 7. 2856 & 0 \\
\hline $\begin{array}{c}\text { Number of } \\
\text { rural } \\
\text { fields } \\
\end{array}$ & 0.3314 & 0.0753 & 7. 0946 & 0 & 0.3456 & 0.0743 & 4. 6499 & 0 \\
\hline $\begin{array}{c}\text { Covered } \\
\text { area }\end{array}$ & -0.0243 & 0.0793 & 4. 3983 & 0.7592 & -0.0217 & 0.0799 & -0.2719 & 0.7856 \\
\hline $\begin{array}{c}\text { Investment } \\
\text { amount }\end{array}$ & 0.0368 & 0.0787 & -0.3065 & 0.6397 & 0.0448 & 0.0791 & 0.5661 & 0.5713 \\
\hline $\begin{array}{l}\text { Number of } \\
\text { field } \\
\text { practitione } \\
\text { rs }\end{array}$ & 0.2105 & 0.0902 & 2. 3334 & 0.0196 & 0.1933 & 0.0851 & 2. 2694 & 0.0232 \\
\hline $\begin{array}{c}\text { Audience } \\
\text { seat }\end{array}$ & 0.2482 & 0.09 & 2. 7559 & 0.0058 & 0.2402 & 0.0902 & 2.6615 & 0.0078 \\
\hline $\mathrm{R} 2$ & 0.9599 & & & & 0.9597 & & & \\
\hline $\log \mathrm{L}$ & 5.583 & & & & 5.6838 & & & \\
\hline AIC & 8.8333 & & & & 7. 0323 & & & \\
\hline $\mathrm{SC}$ & 23. 1732 & & & & 19. 9382 & & & \\
\hline
\end{tabular}

Judging from the goodness of fit R2, SLM and SEM are both superior to OLS. secondly, judging from LogL, AIC and SCL, also due to OLS estimation results, it shows that considering the spatial correlation and heterogeneity, it can better explain the spatial distribution characteristics of sports fields in China. At the same time, $\mathrm{p}=$ 0.041 from the heteroscedasticity test, the significance is greater than $5 \%$. the assumption that there is no heteroscedasticity is accepted, which shows that the model has no heteroscedasticity, and the spatial lag model and the spatial error model are superior to OLS model. At the same time, the residual of OLS estimation result is checked by residual autocorrelation test, moran' $\mathrm{s} i=0.072$, and the probability value is 0.047 , rejecting the assumption that there is no spatial autocorrelation .It further shows that OLS, which ignores spatial autocorrelation, has shortcomings and should choose a spatial econometric model for analysis.

At the same time, we can see that the results of SLM and SEM are the same as OLS. the coefficient symbols of GDP per capita and covered area values are contrary to expectations, and they are negative in all three models. The evaluation of which model to choose needs further verification. According to the criteria proposed by Anselin and others, first look at the R2 value of fitting degree, SLM > SEM > OLS in the three models. Secondly, look at the values of LogL (the bigger the better), AIC and SC (the smaller the better). According to the results in table 3 and table 4, SEM model is better than SLM and OLS model. Finally, look at the coefficient significance test. In the spatial lag model and the spatial error model, the 
per capita GDP, the number of outdoor fields, the number of rural fields, the number of field practitioners and the number of audience seats all passed the $5 \% \mathrm{t}$ significance test. Based on the summary and analysis of all test conclusions, SEM model is the best model.

As mentioned earlier, the indicators of GDP per capita and field covered area are negative in the spatial measurement model. The per capita GDP index did not pass the significance test in OLS model. However, the SLM and SEM models passed the significance test. This shows that GDP per capita has a significant influence on the distribution of sports field in China. However, contrary to the traditional concept, the smaller the density of field in regions with high GDP per capita, the paradox of field distribution appears. This article thinks that it is the imbalance of economic development in China. The distribution of the poor population is extensive and concentrated in the region. In other words, some poor areas in China have more sports fields instead. The poor population is characterized by clusters. It is this characteristic of contiguous poverty that leads to the paradox that the distribution density of sports field in China decreases with the increase of GDP per capita. Incidentally, China's 12th five-year plan for the national basic public service system released in 2012 proposes to continuously promote the equalization of basic public services among regions in view of the regional gap in basic public services. At the same time, in response to the "western development" policy put forward in 2000, 12 provinces, cities and autonomous regions with relatively backward economy in China have been vigorously developed and supported. It also enriches the resources allocated to sports fields.

In addition, the field covered area index is also negative in the spatial measurement model, but all three models show that the t test of the field covered area index coefficient has not passed the significance test. It shows that the influence of the covered area of the stadium on the sports stadium is not obvious. The reason may be that for different regions, the sports fields may have different types of fields, the location of fields and the terrain of the region, etc. These factors have no obvious influence on the field distribution, although they may have important influence on some developed areas or areas with high urban density.

By comparing the sign of the SEM and OLS coefficients, the sign of all coefficients are the same. After confirming that the spatial error model SEM is the best model, it shows that the OLS and SLM models can more accurately reflect the influence of various variables on the number of sports fields. Comparing the coefficients (absolute values) of SEM and OLS models, it is found that the difference in GDP per capita is not large, while the coefficients of the factors such as the number of permanent residents, the number of outdoor sports fields, the covered area, the number of employees and the number of seats for audiences are larger than those of SEM models. Only the number of rural fields and the coefficient value SEM of financial allocation are larger than OLS model. Taken together, it shows that OLS model overestimates the influence of natural factors and social factors (number of resident population, covered area, employees, number of seats for audiences, etc.) on the distribution of sports fields. And the number of villages can represent the government in implementing the plan of equalization of sports 
facilities. The comprehensive financial allocation can show the government's strength in the construction of sports fields and facilities. Both are government macro-control actions. However, the SEM model just corrects the OLS model's overestimation of natural and social factors, while underestimating the government's behavior because of its shortcomings, which further shows that the SEM model can more accurately reflect the characteristics of the spatial distribution of sports fields in China.

\section{Conclusions and suggestions}

Based on the above research, the main conclusion drawn in this paper is that the spatial econometric model is more advantageous than ordinary regression in explaining the spatial heterogeneity of sports field distribution. The conclusion is more practical.

On this basis, the following policy suggestions are put forward: (1) when formulating the development and use of sports fields, the spatial correlation of regional sports field resource distribution should be considered. Taking into account the mutual influence of various factors in neighboring regions, promoting the formation of a cross-regional mechanism for the development and utilization of sports field resources and establish an integrated policy for the development and development of sports field resources.(2) The development of sports cause and the number of sports fields are not absolutely corresponding. Through reasonable arrangement of population, area, economic development and the proportion of sports fields and waste paper, it can realize the development of new sports field resources and rationally utilize and develop the existing sports field resources.(3) The government should actively guide, from the perspective of the overall allocation of sports fields resources, the construction of sports fields resources that can be suitable for local people to use, make use of and develop the local competitive sports level, and undertake high-level sports competitions. Avoid repeated inefficient investment in similar regions, not only give full play to the regional characteristics, but also protect the resources of sports fields.

\section{References}

[1] Pang Hao. Econometrics [M]. Science Press, 2007

[2] Gao Tiemei. Econometric Analysis Method and Modeling [M]. Tsinghua University Publishing House, 2006

[3] Compilation of Data from the 6th National Sports Fields Census [M]. Economic Department of the State Sport General Administration.2014.

[4] He Li, Shi Hui. Comparative Study on Index System and Census Information of all Previous Fields in China [J]. Sports Culture Guide, 2014, 31 (2): 198 202.

[5] Lei Zhe, Hou Bin. Analysis of Public Sports Fitness Facilities Planning in China [J ]. Sports Culture Guide, 2010, (7): 62 - 65 
[6] State Sport General Administration. Circular on Carrying out the sixth National Sports Fields Census: Physical Culture and Sports Institute [2013] No. 41(A ). Beijing: National Sports Fields Census Office.2013.

[7] Fifth National Sports Fields Census Data Bulletin [J]. Sports Science and Technology Literature Research, 2005,23 (4): 28.

[8] Xie Hongwei, Zhao ke, Zhang Hongyan, Jiang Hongyu. Economic Analysis of Effective Supply of Sports Fields and Facilities in Urban Residential Communities [ J ]. Sports Science, 2011.31(11): 13-20.

[9] $\mathrm{Xu}$ Bin. Simulation Analysis of the Influence of Spatial Weight Matrix on Moran' s I Index [D], Nanjing: Master's Degree Thesis of Nanjing Normal University.

[10] Wu Yuming. Applied Research on Spatial Econometric Model in Provincial R \& D and Innovation [J]. Quantitative Economic, Technological and Economic Research, 2006 (5): 51 - 54.

[11] Cadot, O.; Röller, L.-H. and Stephan, A.: Contribution to Productivity or Pork Barrel? The Two Faces of infrastructure Investment, Journal of Public Economics, 90(6-7): 1133-1153, 2006.

[12] Chen, P.-C.; Yu, M.-M.; Chang, C.-C. and Hsu, S.-H.: Total Factor Productivity Growth in China's Agricultural Sector, China Economic Review, 19(4): 580-593, 2008.

[13] Gibson, J. and Olivia, S.: The Effect of Infrastructure Access and Quality on Non-Farm Enterprises in Rural Indonesia, World Development, in press, corrected proof, 2009.

[14] Ulubasoglu, M. A. and Cardak, B. A.: International Comparisons of Ruralurban Educational Attainment: Data and Determinants, European Economic Review, 51(7): 1828-1857, 2007.

[15] Yang Yu, Zhang Jinnian. notes on location selection of sports center [J ]. Sports Teaching and Scientific Research, 1981 (1): 47 - 54

[16] Tracy H ,Comer Jonathan C. changing intra-Urban Location Patterns of Major League sports Facilities[j].the professional geographer, 2000,52(1): 105-120

[17] Daade Robert a. Professional Sports As Catalysts For Metropolitan Economic Development [J].Journal Of Urban Affairs,1996,18(1):1-17

[18] Yin ling. Reflections on the Existing Problems of Community Sports Fields and Facilities in China [J]. Journal of Chengdu Physical Education Institute, 2008 (34): 28 - 31

[19] Gao yali, Yang Tao, Quan Deqing, Cai jun, Wei juanli. Statistical Analysis of the Development and Utilization of National SportsFields from 2008 to 2009 [ J] Journal of Xi' an Institute of Physical Education.2013(6): 665-670

[20] Frank P,Jozsa, American Sports Empire: How The Leagues Breed Success[M].North Caralina: Praeger Publishers,2003

[21] Zeng Jianming, Wang Jian. Research on Spatial layout of Large Stadiums and Gymnasiums in China [J ]. Sports Science, 2014,34 (7): 61 - 78

[22] Xu Yueyun, Chen Xiaming. Current Situation and Development Path of Regional Sports Fields Construction: taking Quanzhou city as an example [J ]Journal of Capital Institute of Physical Education, 2016.28 (2): 114 - 121. 